\title{
Editorial RES 3/2021
}

\section{Andra Jugănaru, Corina Cioltei-HopÂrtean}

This issue of Review of Ecumenical Studies gathers contributions which reveal instances of religious identities from different periods and areas, tributary to the social, political, economic, and cultural contexts of their times. All these articles show the various and complex ways in which religious identities were constructed, expressed, and used from Late Antiquity until the Middle Ages, and with effects even today.

Harri Huovinen describes the process in which the ecclesiological identity of the candidates to

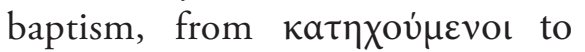
$\varphi \omega \tau \iota \zeta{ }^{\prime} \mu \varepsilon v o l$, was formed by examining the familial terminology used in the writings of Cyril of Alexandria (c. 315-387). The filial and fraternal terminology is not used only metaphorically. Neither does it express an egalitarianism or the presence of hierarchical relations. Instead, these terms are "anticipatory, prescriptive and descriptive," as they reinforce the ecclesial unity of the Christian community, already expressed from the pre-baptismal phase and accomplished at the end
Die vorliegende Ausgabe der Review of Ecumenical Studies enthält Beiträge zur Frage, wie sich religiöse Identitäten in unterschiedlichen Epochen und Regionen ausbilden und welchen Einfluss dabei die sozialen, politischen, wirtschaftlichen und kulturellen Konstellationen der jeweiligen Zeit haben. Solche religiöse Identitäten kommen auf vielfältige und komplexe Art zustande und werden unterschiedlich zum Ausdruck gebracht. In den Beiträgen ist besonders die Zeitspanne von der Spätantike bis zum Mittelalter im Blick, wobei auch ihre weitere Wirkung bis in die Gegenwart nicht ausgeblendet wird.

Harri Huovinen beschreibt, wie sich die kirchliche Identität der Taufkandidaten im Übergang von $\kappa a \tau \eta \chi 0-$

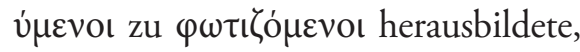
wobei er die Terminologie aus dem Bereich der Familie untersucht, wie sie in den Schriften von Kyrill von Alexandrien (ca. 315-387) zu finden ist. Die Rede von Kindern und Geschwistern wird nicht nur metaphorisch verwendet und ist auch kein Ausdruck von Egalitarismus oder von hierarchischen Beziehungen. Diese Begriffe sind viel-

*Andra Jugănaru, post-doctoral fellow, Aristotle University of Thessaloniki, Str. Calotești, nr. 4, et. 4, ap. 5, sect. 3, București, 030593, andra.juganaru@gmail.com;

Corina Cioltei-Hopârtean, Referent at Institutul de Cercetari Socio-Umane Sibiu, Bulevardul Victoriei 40, Sibiu, Romania, corinahopartean@yahoo.com. 
of the gradual process of one's prebaptismal transformation.

The religious, gender, and sexual identities in the Life of Pelagia, a fifth-century example of a transvestite saint, constitute the focus of Mariana Bodnaruk's contribution. This text - initiating a genre, which enjoyed great popularity in Byzantium until the eleventh century - tells the story of a harlot, Pelagia, who at some point in her existence repents and converts to asceticism disguised in male attire and taking a man's name, Pelagius. This article explores the way in which this hagiography (belonging to a type of Late Antique texts, which in itself mediates social identity at the intersection of religious, gender, and sexual identities), through intertextuality, builds gender fluidity. Besides, the gendered spiritual progress, virtue, and asceticism are relevant for the construction of Christian identity in Late Antiquity.

The article of Szabolcs András reveals the way in which a doctrinal debate, the Filioque controversy - shapes the construction of religious, cultural, ethnic, and political self-representation in the long run. In the Balkans, in the late Middle Ages, the appurtenance to a specific theological stance could be used as a social criterion by which certain groups distinguished themselves. On the one hand, the political events occurred between the eighth and the eleventh centuries stood mehr „vorgreifend, präskriptiv und beschreibend" zu verstehen, da sie die kirchliche Einheit der christlichen Gemeinschaft bekräftigen, die im Ansatz bereits in der Zeit vor der Taufe da war und sich in einem Prozess der allmählichen Transformation voll entfaltete.

Die religiösen, geschlechtlichen und sexuellen Identitäten im Leben von Pelagia, einem Beispiel einer Transvestitin und Heiligen aus dem fünften Jahrhundert, stehen im Mittelpunkt des Beitrags von Mariana Bodnaruk. Der von ihr besprochene Text gehört zu einer Gattung, die sich in Byzanz bis ins 11. Jh. großer Beliebtheit erfreute. Er erzählt die Geschichte einer Hure, Pelagia, die an einem gewissen Punkt in ihrem Leben Reue empfindet, sich zu einem asketischen Leben bekehrt, sich als Mann verkleidet und den Namen Pelagius annimmt. Bodnaruk untersucht die Art und Weise, wie diese Hagiographie (die zu einer Gattung spätantiker Texte gehört, die soziale Identität an der Schnittstelle mit religiösen, geschlechtlichen und sexuellen Identitäten vermitteln) durch Intertextualität geschlechtliche Fluidität aufbaut. Daneben sind der geschlechtsspezifische geistliche Fortschritt, die Tugend und die Askese für die Konstruktion christlicher Identität in der Spätantike relevant.

Der Artikel von Szabolcs András zeigt auf, wie eine Lehrdebatte - die „Filioque-Kontroverse” - die Konstruktion religiöser, kultureller, ethnischer und politischer Selbstdarstellung langfristig prägt. Auf dem Balkan konnte im Spätmittelalter die Zugehö- 
at the core of the dogmatic identity formation. On the other hand, between the thirteenth and the fifteenth centuries, an internal renewal, termed Palamism, influenced all the levels of the society. The internal division and the external threats which the Orthodox Church had to face across centuries, as well as the social, cultural, and ethnic self-identification throughout this period, were part of the process of dogmatic identification, with the Filioque being its trigger.

There is a period during the Early Middle Ages when religious identity comes hard to define. Written sources are lacking and archaeology becomes the main, if not the only, science that brings information regarding the people's rite and ritual. This is a matter sought after by archaeologists everywhere from Hungary, to Romania, Bulgaria and mainly all around eastern and south-eastern Europe where the fall of the Roman Empire had led to a decentralized territory. Adrian S,ovrea has chosen to depict the archaeological situation of funeral rite and ritual for a micro-region in Transylvania, namely along the middle valley of the Târnava Mare River. His analysis shows how pagan funeral elements where mixed with Christian one between the ninth to twelfth centuries.

In order to spread and fulfill its purpose, namely that of creating an identity, religion needs a structured core, be that the institution of the rigkeit zu einer bestimmten theologischen Haltung als soziales Unterscheidungskriterium bestimmter Gruppen dienen. Einerseits spielten die politischen Ereignisse zwischen dem 8. und 11. Jahrhundert eine zentrale Rolle in der Ausformung der dogmatisch-theologischen Identität, andererseits beeinflusste zwischen dem 13. und dem 15. Jahrhundert eine innere Erneuerung, die als Palamismus bezeichnet wird, alle Ebenen der Gesellschaft. Die innere Spaltung und die äußeren Bedrohungen, denen sich die orthodoxe Kirche über Jahrhunderte hinweg stellen musste, sowie die soziale, kulturelle und ethnische Selbstidentifikation während dieser Zeit waren Teil des dogmatischen Identifikationsprozesses, dessen Auslöser das Filioque war.

Für eine gewisse Zeitspanne im frühen Mittelalter ist religiöse Identität schwer zu definieren. Schriftliche Quellen fehlen, und die Archäologie wird die wichtigste oder sogar einzige Wissenschaft, die Informationen über die Riten und Rituale der Menschen liefert. Daran arbeiten Archäologen vielerorts, in Ungarn, Rumänien und Bulgarien, ja in ganz Ost- und Südosteuropa, wo der Untergang des Römischen Reiches zu einer Gebietsaufteilung geführt hatte. Adrian Șovrea stellt die archäologische Situation von Bestattungsriten und -ritualen für eine Mikroregion in Siebenbürgen dar, und zwar entlang des mittleren Tals des Flusses Târnava Mare, der Großen Kockel. Seine Analyse zeigt, wie sich zwischen dem 9. und 12. 
Church, royal authority or vectors such as religious orders, monastic, mendicant or military. Based on Raul Todika's research, the readers come across an example of how religious borders were pushed and expanded between the twelfth to fourteenth centuries with the help of the Teutonic Knights. Analyzing the military orders of the Teutonic Knights as an agent of the Holy See, whose aim was to enlarge the margins of the Christianitas, the author brings forth the episode of their presence within a marginal area of the Hungarian kingdom, namely that of the Burzenland, in southeastern Transylvania.

Another question of religious identity during the Middle Ages is that of co-existing denominations, the Western faith and the Eastern one, within the same territory. Ioana Tereza Pop has chosen to delve into this topic based on the realities in Maramureș county, a territory southwest of the Tisza River (of which one third belongs nowadays to Romania) between the fourteenth to sixteenth centuries. This territory under Hungarian rule made it possible for people of both faiths to "accept" each other. On the one hand, the Catholic communities flourished within the royal cities, Catholic monasteries such as the Pauline one in Remețiwas given the support of Hungarian authorities and, on the other hand, the Romanian communities lived under the Eastern faith in their own
Jahrhundert heidnische Begräbniselemente mit christlichen vermischten.

Um sich auszubreiten und ihren identitätsstiftenden Zweck zu erfüllen, braucht Religion einen strukturierten Träger. Dies kann die Institution der Kirche oder die königliche Autorität sein, aber auch religiöse Orden: Klöster, Bettelorden oder geistliche Ritterorden. Die Untersuchungen von Raul Todika führen dem Leser ein Beispiel vor Augen, wie zwischen dem 12. und 14. Jahrhundert mit Hilfe des Deutschen Ordens religiöse Grenzen verschoben und erweitert wurden. Das Ziel des Deutschen Ordens war es, im Auftrag des Heiligen Stuhls die Grenzen der Christianitas zu erweitern; dies gilt auch für das Randgebiet des ungarischen Königreichs, das der $\mathrm{Au}-$ tor untersucht, nämlich das Burzenland im südöstlichen Siebenbürgen.

Eine andere Frage der religiösen Identität im Mittelalter ist diejenige der Koexistenz von Konfessionen, des westlichen und des östlichen Christentums, innerhalb desselben Territoriums. Ioana Tereza Pop behandelt dieses Thema für die Zeitspanne zwischen dem 14. und 16. Jahrhundert anhand der Situation im Kreis Maramureș, einem Gebiet südwestlich des Flusses Theiß, das heute zu einem Drittel zu Rumänien gehört. Dieses Territorium unter ungarischer Herrschaft ermöglichte es den Menschen beider Glaubensrichtungen, sich gegenseitig ,anzunehmen“. Die katholischen Gemeinden blühten in den Städten auf, die direkt dem König unterstanden - katholische Klöster wie 
settlements. Furthermore, despite a Catholic organization of the area, there are cases when representatives of the authorities had requested and received the patronage of the patriarch for their monastery during the fourteenth century.

Raluca Prelipceanu introduces a reinterpretation of known paintings belonging to eighteenth and nineteenth century Transylvanian churches, from the perspectives of Orthodox and Catholic iconography. Besides these sources, painters' signatures and visitation records and contracts form the basis for the analysis of the painters' status shift, from craftsmen to artists.

Among the new scholarly trends of diachronical comparisons of anthropological concepts in different areas, this issue of RES offers to the large public insights into a variety of ways in which construction and representation of religious and social identities was expressed through written, archaeological, iconographical, and archival evidence. Besides, it also brings to light instances of the evolution, change, and interplay of these methods of self-representation or identity building from Late Antiquity to the Middle Ages and even up to the present day. das Paulinerkloster in Remeți erhielten die Unterstützung der ungarischen Behörden. Die rumänischen Gemeinden ihrerseits konnten ihren orthodoxen Glauben in ihren eigenen Siedlungsgebieten pflegen. Darüber hinaus gibt es trotz katholischer Oberherrschaft Fälle, in denen Vertreter der Behörden im 14. Jahrhundert die Schirmherrschaft des Patriarchen für ihr Kloster beantragt und erhalten haben.

Raluca Prelipceanu stellt eine Neuinterpretation bekannter Gemälde der siebenbürgischen Kirchen des 18.-19. Jahrhunderts aus der Perspektive der orthodoxen und katholischen Ikonographie vor. Neben diesen Quellen bilden Malerunterschriften sowie Besuchsprotokolle und Verträge die Grundlage für die Analyse des Statuswandels der Maler vom Handwerker zum Künstler.

Neuere Forschung in verschiedenen Bereichen hat sich diachronischen Vergleichen anthropologischer Konzepte zugewandt; auf dieser Linie steht auch die vorliegende Ausgabe RES. Sie will Einblicke in eine Vielzahl von Möglichkeiten vermitteln, wie sich die Konstruktion und Repräsentation religiöser und sozialer Identitäten anhand von schriftlichen, archäologischen, ikonografischen und archivarischen Zeugnissen belegen lässt. Dabei werden Beispiele für die Entwicklung, den Wandel und das Zusammenspiel dieser Formen der Selbstdarstellung oder Identitätsbildung von der Spätantike über das Mittelalter bis in die Gegenwart besprochen. 